country in relation to the musk rat menace, and particularly to the fact that now that the keeping of musk rats is prohibited except under the strictest regulations against their escape, the musk rat farmers have turned their attention to the coypu or nutria, an aquatic South American rodent. The latter animal is as large as a beaver, but has a tapering tail ; it lives in burrows, and its fur is brown, soft and dense. The Trustees decided to recommend to the authorities concerned that the nutria should, like the musk rat, be scheduled as an animal the import of which is prohibited and which shall be kept only under licence.

\section{Bartholomew Diaz off Cape Colony}

Mr. S. A. Mumford, of Tresta, Farley, Salisbury, Wilts., has written stating that the voyage of Bartholomew Diaz, when he touched the south coast of Cape Colony, is usually quoted as having taken place between August 1486 and December 1487, whereas in our "Calendar of Geographical Discovery" (NATURE, vol. 129, p. 177, Jan. 30, 1932), a note on the voyage appears under the date Feb. 3, 1488. The date given in our columns is based on a marginal note, probably by Christopher Columbus himself, on folio 13 of a copy of Pierre D'Ailly's "Imago Mundi", which fixes Diaz's return to Lisbon in the month of December 1488. The writer says he was present at Diaz's interview with the King of Portugal when the explorer's chart was shown and discussed. The "Imago Mundi" is at present in the Colombina at Seville.

\section{Announcements}

THE De Morgan medal of the London Mathematical Society, which is awarded triennially, has this year been awarded to Bertrand Russell in recognition of his mathematical work. The medal will be presented at the annual general meeting of the Society which will be held at Burlington House, Piccadilly, London, W.I, on November 10 , at 5 P.M.

AT the annual statutory meeting of the Royal Society of Edinburgh held on October 24, the following Council was elected: President: Sir E. A. Sharpey-Schafer; Vice-Presidents : Prof. J. H. Ashworth ; Dr. A. Logan Turner ; Dr. J. B. Clark ; Prof. James Ritchie; Sir Thomas Holland; The Hon. Lord Sands; General Secretary : Prof. R. A. Sampson; Secretaries to Ordinary Meetings: Prof. C. G. Darwin and Prof. F. A. E. Crew ; Treasurer : Dr. James Watt; Curator of Library and Museum : Prof. D'Arcy W. Thompson; Councillors: Dr. Murray Macgregor; Dr. A. Crichton Mitchell; Prof. P. T. Herring; Prof. James P. Kendall; Prof. T. M. MacRobert ; Prof. Godfrey H. Thomson; Dr. Malcolm Wilson; Prof. E. B. Bailey; Prof. J. C. Brash ; Prof. A. J. Clark ; Prof. A. G. Ogilvie; Prof. E. M. Wedderburn.

Prof. E. N. DA. C. Andrade will give four lectures at the Royal Institution on Tuesdays at 5.15 P.M. beginning November 1 on "Rays and Radiations".
The course is an experiment in the treatment of a branch of modern physical science on the lines of the popular Christmas Lectures to juveniles, but Prof. Andrade will address himself on this occasion to the grown-ups. He will talk and show experiments on the gamma and ultra-violet radiations, $\mathrm{X}$-rays, infra-red rays, and the particle radiations which have been used in the investigation of the inner structure of the atom. Prof. Lancelot Hogben will give three lectures, also on Tuesdays at 5.15 P.M., beginning November 29, on "Colour Change in Animals". The mechanism of colour change in such a well-known example as the chameleon will be discussed, and compared with that in other animals subject to colour changes, such as the frog, the salamander and certain fishes.

The Council of the Institution of Civil Engineers has awarded the Indian Premium for the session 1931-32 to Sir Bernard D'O. Darley (Bahawalpur, Punjab), and the Webb Prize for the session to Mr. B. G. White (London) for papers read and discussed at ordinary meetings of the Institution. The following awards for the session have been made for "Selected Engineering Papers", published without discussion :A Telford Gold Medal to Dr. J. F. Baker (Abbots Langley); Telford Premiums to Mr. William Muirhead (London), Mr. E. B. Cocks (London), Dr. James Orr (Glasgow), Dr. W. J. Walker (Johannesburg), and Mr. W. C. Ash (Vizagapatam, India); and a Crampton Prize to Mr. L. St. C. Rundlett (Rangoon, Burma). Awards have also been made for papers read at students' meetings in London, or by students before meetings of local associations, as follows :The James Forrest Medal and a Miller Prize to Mr. D. J. Anderson (Glasgow), and Miller Prizes to Messrs. A. C. L. Browne (London), C. W. Scott (London), A. J. P. Pashler (Birmingham), W. D. MeFadyean (London), Granville Berry (London), P. J. Stuckey (Cardiff), W. H. Morgan (Newcastle), R. R. W. Grigson (London), E. A. Turner (London), and Frank Breakwell (London).

Applications are invited for the following appoint. ments, on or before the dates mentioned :- $\mathbf{A}$ University. lecturer and a University demonstrator in biochemistry at the University of CambridgeThe Professor, School of Biochemistry, Cambridge (Nov. 9). A junior assistant and guide-lecturer at the City of Birmingham Museum and Art GalleryThe Keeper (Nov. 11). An Armourers and Brasiers research fellow in metallurgy of the Royal SocietyThe Assistant Secretary, The Royal Society, Burlington House, W.1 (Nov. 14). A lecturer and tutor in hygiene in the Department of Education at the University of Bristol-The Secretary and Registrar (Nov. 19).

Erratum.-Letter on "Possible Existence of Multiply Charged Particles of Mass One" by Dr. M. Delbrück in NATURE for October $22:$ p. 627, col. 1, line 33, for "an $\alpha$-particle is stable ..." read "a particle in the $\alpha$-particle is stable. . . ."

No. 3287, VoL. 1301 